\title{
Comparison of international mine reclamation bonding systems with recommendations for China
}

\author{
Linlin Cheng ${ }^{1} \cdot$ Jeffrey G. Skousen ${ }^{2}$
}

Received: 12 December 2016/Revised: 10 February 2017/Accepted: 13 March 2017/Published online: 24 March 2017

(C) The Author(s) 2017. This article is an open access publication

\begin{abstract}
Mine reclamation bonds are used in countries with mineral mining to ensure that reclamation of the mined area is completed. The United States, Canada, and Australia are countries with established mine reclamation bond programs, with the United States coal system having been in place since 1977. China implemented a bonding system in 1998 and by 2013 all 31 provinces had established a system. An effective bonding system must be conditioned on fair and enforceable nationwide reclamation standard, stimulate companies to conduct reclamation by forming economic incentives rather than penalties that become a liability, and allow for full public participation. Based on these principles, this paper compares seven important factors for a successful reclamation bonding system: laws and regulations, administrative authority, bond types, bond size, calculation method, bond release, and public participation. The results show variation in policies and procedures for bonding among countries. Using principles and policies primarily from the United States, China should establish a national reclamation bonding system with legislation that forms a national authority to oversee and enforce reclamation standards and bond requirements. In addition, China can expand bond financial types and strategies, set the size of reclamation bonds at the level of a third-party reclamation cost, and set unified standards for calculation. Phased bond release should be established with specific reclamation criteria for each phase of release. Finally, bonding regulations should clearly identify opportunities for full public participation in the process.
\end{abstract}

Keywords Mining legislation · Administrative authority · Bond types · Size of bond · Calculation method · Bond release . Public participation

\section{Introduction}

Mining produces materials that are essential to human needs, but the mining process also disturbs the environment, including the ecosystem and organisms, land surface,

Linlin Cheng

chll@cumtb.edu.cn

Jeffrey G. Skousen

jskousen@wvu.edu

1 Department of Surveying and Land Use, School of Geoscience and Surveying Engineering, China University of Mining and Technology (Beijing), D11 Xueyuan Road, Haidian District, Beijing 100083, China

2 Division of Plant and Soil Sciences, West Virginia University, Morgantown, WV 26506-6108, USA and hydrologic balance (Zipper et al. 2011). In the United States alone, from 1930 to 2000, coal mining altered 2.5 million ha of natural landscape, most of that land originally being forested landscapes (MacDonald et al. 2015). In Canada, coal is mined primarily in the three western Provinces of British Columbia, Alberta and Saskatchewan with estimates of 200000 ha of land being disturbed (Fedkenheuer and Macyk 2000). According to the Queensland Resources Council, there will be as much as 120000 ha of land disturbed from mining by 2020 in central Queensland, Australia (Slezak and Robertson 2016). Coal mining in China produced over 2 billion metric tons of raw coal in 2012, with much of that coming from underground mines. Estimates for land surface impacts from subsidence are as high as 1 million ha ( $\mathrm{Hu} 2009)$.

Mine reclamation is required by the governments of most countries. Before the mining process begins, 
companies develop mining plans that outline the process of land disturbance to obtain the mineral resource. The mining plan also outlines a reclamation procedure to restore the land to a productive post-mining land use (Skousen and Zipper 2014). Common reclamation goals include backfilling and regrading to a specified landform, replacing topsoil, and establishing a vegetation cover to meet the land use goals of the landowner. The mining plan and reclamation plan are the basis for a mining permit issued by the regulatory authority with the objective of mitigating mining impacts to land and water.

As part of the mining permit application, the mining operator is also required to post a reclamation bond. The reclamation bond provides a financial guarantee that the land being disturbed for the operation of the mine will be reclaimed to an acceptable condition. If the operator successfully completes reclamation according to the requirements of the reclamation plan, the reclamation bond is released to the operator. If the operator fails to reclaim the site and all means are exhausted to compel the operator to reclaim the site, then the reclamation bond is forfeited and used to reclaim the land under the supervision of the regulatory authority.

\subsection{Reclamation bond types}

Reclamation bonds can be provided or purchased in several ways. The most commonly used types are as below.

1. Companies can deposit cash or liquid assets directly into an account that is accessible to the regulatory authority. Assets such as certificates of deposit, bank guarantees, first-lien interests in real estate, and other financial holdings may be deposited.

2. Companies can purchase an insurance policy from a financial surety provider that will pay out the insured amount of reclamation bond if the mining permit is forfeited. The insurance policy is for a specified length of time for which the company pays a premium for the coverage.

3. A surety bond is a three-party contract between a mining company, a surety company, and a regulatory agency. The mining company is obligated to conduct reclamation and the surety company is a secondary source of funds to the mining company. The mining company is still the primary source of funds for reclamation.

4. A trust fund is a financial account managed by a thirdparty or trustee. The mining company places an agreed-upon amount into a trust fund and a designated trustee manages the funds provided by the mining company. The funds become payable to the regulatory authority if the company fails to perform reclamation.
5. Companies can be self-bonded or provide corporate guarantees. This means that the company relies on its own financial strength to provide assurance for reclamation by meeting certain financial tests established by the regulatory authority without depositing assets into an account directly or the use of a separate surety company.

6. A bond pool is an alternative bonding program where members in the bond pool pay membership and resource extraction fees. The money in the bond pool increases in size with fee collection and investment options. The amount or rate at which a specific member pays into the bond pool is conditional and based on their risk history. Companies may be assigned a rating of $\mathrm{A}, \mathrm{B}$, or $\mathrm{C}$, based on their compliance history with permit obligations.

\subsection{Factors considered when determining bond amount}

Most reclamation bond calculations include estimates of the potential disturbance area and other liabilities such as infrastructure or water treatment. The amount of money for the reclamation bond is usually based on an analysis of anticipated liabilities in the event of forfeiture. Most regulatory authorities have a process for calculating liabilities and thus have a way to determine bond amounts for a given property based on site factors and the nature of the disturbance and the jurisdiction's environmental and land use requirements. The liability analysis is based on several considerations such as the period of operation, size and depth of the disturbance, underground and surface water handling and treatment, equipment and facilities removal and disposal, hazardous waste disposal, landscape restoration and earthwork, topsoil replacement, and revegetation. For example, the United States Forest Service summarized the factors that it uses to determine bond amounts on United States federal lands with the following (Marks et al. 2004): (1) interim operations and maintenance, (2) hazardous materials, (3) water quality, (4) demolition, removal and disposal of uncontaminated structures, equipment and materials, (5) earthwork, (6) revegetation, (7) mitigation, (8) long term operation, maintenance and monitoring.

\subsection{Use of bonding}

Bonding offers several advantages. It provides an assurance that a disturbance will be reclaimed either by the mining company or the regulator or a combination of both. It also provides the funding or a mechanism for funding that is needed to complete reclamation. One disadvantage of 
bonding is the added cost to the mining company for setting aside sufficient funds before the disturbance starts. The capital investment of placing a large sum of cash in a bond fund or financial account can put the company in fiscal difficulty from the start. Another disadvantage is that the funds allocated for the bond initially may become insufficient to complete reclamation later when new standards or different reclamation requirements emerge. Therefore, some type of periodic review or recalculation is needed.

Although reclamation bonding may have some disadvantages (Shogren et al. 1993), international experience has proven that the bonding procedure is an effective and reasonable practice to ensure reclamation if a company defaults on permit obligations (McLeod 2000; Cheng 2009). As such, the use of bonding is common in the mining industry worldwide (Gerard 2000; Cheng 2009).

One of the first United States laws requiring a reclamation bond in coal mining was Pennsylvania's Anthracite Strip Mining Law of 1947. Other United States eastern states followed this approach with gradual increases in reclamation requirements during the ensuing 30 years. In 1977, the national Surface Mining Control and Reclamation Act (SMCRA) was passed by the United States Congress, which included strong bond provisions to ensure reclamation occurred if the mining company defaulted on its obligations.

To promote mine reclamation, China implemented a bonding system in 1998 in Zhejiang province. By 2013, all 31 provinces (including autonomous regions or municipalities that are directly under the central government) have established bond systems. But it is relatively new and has not developed some of the provisions found in bonding systems of other countries. Currently, only $25 \%$ of land disturbed in China has been reclaimed (Liu 2011), while countries with a longer history of bonding systems such as the United States and Australia have $80 \%$ of disturbed lands reclaimed (Luo and Wang 2010). Therefore, the older bonding programs of other countries may provide successful options and practices for reclamation bonds in China.

\subsection{Standards for the evaluation of reclamation bonding system}

An effective reclamation bonding system should have the following features (Cheng 2009):

1. Must be based on fair and enforceable nationwide reclamation standards for mining companies.

A successful reclamation bonding system should be a 'fair' system. That is, all the mining companies throughout the country should face the same requirements and costs per unit of disturbed area for reclamation. Reclamation bonds help to ensure reclamation of the disturbed area and to enhance public welfare and attitude.
2. Stimulate companies to conduct reclamation by forming economic incentives rather than penalties that become a liability.

Reclamation is no longer viewed as an extra cost or option for mining companies; rather it is a rule that mining companies reclaim the land and undo the damage resulting from the mining operation. This principle reflects the proper ethical philosophy for environmental protection. The main purpose of reclamation bonding is to make the mining companies bear the external cost caused by mining activities and perform reclamation work by themselves, not to collect a huge reclamation fund for the regulatory authority. Therefore, an effective reclamation bonding system should achieve this purpose.

3. Allow for full public participation.

The well-being of society is based on a clean and healthy environment. The public is affected both positively and negatively by mining operations. They receive the benefits of economic development and jobs the company provides, but they also bear the burden of a poor environment in the long term if there is little or no reclamation. Therefore, the public should have the right to participate in mine permitting and the reclamation bonding system. In addition, public participation can create a social consciousness that can be both for and against mining operations, place strong pressure on the credibility and reputation of mining companies, and supervise or demand reclamation performance. Thus, the purpose of reclamation bonding systems can be more easily achieved with public participation.

Important factors of a bonding system are: (1) laws and regulations which are passed to set standards and enforcement, (2) authority or agency that enforces laws and administers the reclamation bond, (3) type of bond to be collected, (4) size of the bond, (5) method of calculation, (6) provisions for release of the bond, and (7) public participation. The objective of this paper is to use the above factors to compare bonding systems in four countries (United States, Australia, Canada, and China) and provide recommendations for a sustainable and effective bonding system in China.

\section{Current bonding systems in the United States, Australia, Canada, and China}

\subsection{The United States}

All coal mining operations in the United States are subject to state and federal laws governing reclamation performance and bonding requirements. While laws exist for non-coal resource extraction, regulation of the coal 
industry is significantly more mature and detailed than that found for the non-coal mining industry (Gorton 2013).Therefore, the bonding system for the United States coal industry will be used as the example.

\subsubsection{Laws and regulations}

Surface coal mines prior to 1950 in the United States were generally left with little to no reclamation. As government regulations progressed, mining companies were required to backfill the area and plant grasses or trees (Gorman et al. 2001; Skousen et al. 2006). During the ensuing 30 years, more requirements were instituted to promote reclamation and some states had more stringent laws and regulations, and some had a reclamation bond. When the Surface Mining Control and Reclamation Act was passed in 1977 (SMCRA), the United States mining companies were required to post a reclamation bond as part of the mining permit to ensure that the regulatory authority would have sufficient funds to reclaim the site if the company failed to complete the reclamation plan approved in the permit. The Surface Mining Control and Reclamation Act established the legal requirement of reclamation bonds and created a federal agency to implement the provisions of the act (Code of Federal Regulations Title 30, Chapter 25, Section 1259). This federal agency, the Office of Surface Mining Reclamation and Enforcement (OSMRE), has established detailed provisions for reclamation bonds (Office of Surface Mining Reclamation and Enforcement 2000a, b). 'Primacy' means that a state assumes the primary enforcement responsibility. Most coal-producing states have 'primacy' to enforce the Surface Mining Control and Reclamation Act and have enacted their own state statutes, which meet or exceed the national regulatory requirements to control environmental impacts of coal mining activities (Gorton 2013).

\subsubsection{Administrative authority}

The Office of Surface Mining Reclamation and Enforcement is the federal administrative authority governing the provisions for reclamation bonds. The Office's objective is to ensure that citizens and the environment are protected during mining and that the land is restored to beneficial uses when mining is finished. The headquarters of OSMRE are located in Washington DC with three regional offices in the Appalachian, Mid-Continent, and Western regions. Besides the management of reclamation bonds, it also provides technical training both in the legal and administrative aspects of bonding and in the calculation of reclamation bond amounts.

For states with primacy, reclamation standards and enforcement are administered by their own state reclamation agency. The OSMRE has the right of regular and special inspections in an oversight role. If OSMRE finds that a state regulatory authority has not taken appropriate action or shown good cause, it may issue a federal notice of violation or take other enforcement action directly against the mining company or permit holder (Power 2010).

\subsubsection{Bond types}

Several types of reclamation bonds are available to companies in the United States: (1) cash; (2) certificates of deposit; (3) first-lien interests in real estate; (4) letters of credit; (5) federal, state, or municipal bonds; (6) investmentgrade securities; (7) corporate surety bonds; and (8) selfbonds. Bond types vary from state to state but they must be one of the types recognized by OSMRE (Office of Surface Mining Reclamation and Enforcement 2016). Some states such as Colorado, North Dakota and Wyoming accept any combination of these types of bonds, while Montana does not allow self-bonding. Some states authorize or require mining companies to participate in a "bond pool." Bond pools gained popularity in the 1990s and by 2014, six states had utilized some form of bond pool (Conrad 2014).

\subsubsection{Size of the bond}

According to the Surface Mining Control and Reclamation Act, the performance bond provides a guarantee that funds will be available to the regulatory authority to complete the approved reclamation plan in the event that the mining company fails to do so (Office of Surface Mining Reclamation and Enforcement 2000a, b). It should be based on, but not limited to, the estimated cost of the reclamation plan submitted by the permit applicant and should reflect the probable difficulty of reclamation, giving consideration to such factors as topography, geology, hydrology, and revegetation. The OSMRE wrote a guidance document called the Handbook for Calculation of Reclamation Bond Amounts (Office of Surface Mining Reclamation and Enforcement 2000a, b). The handbook's bond calculation assumed that the bond amount would be sufficient to engage a third-party contractor to complete the reclamation plan and to reflect the worst-case scenario (or the maximum reclamation cost liability). It also required that the liability calculation be based on at least two estimates from the OSMRE and a third-party reclamation entity, taking into account that unanticipated events may increase the reclamation liability. The minimum amount of the bond for one permitted parcel is $\$ 10000$.

\subsubsection{Bond calculation}

The Handbook for Calculation of Reclamation Bond Amounts made a detailed description of the five major 
steps in bond calculation (Office of Surface Mining Reclamation and Enforcement 2000a, b).

1. Determine the point of maximum reclamation cost liability.

2. Estimate direct reclamation costs such as earthmoving, revegetation, and the removal and demolition of structures not to be retained as part of the post-mining land use.

3. Adjust direct costs for inflation.

4. Estimate indirect reclamation costs, including contractor and equipment mobilization and demobilization charges, contingency allowances, redesign expenses (including surveying, aerial photography, and monitoring in support of this effort), profit and overhead, and contract management fees.

5. Calculate the total bond amount.

The Handbook is used when calculating bonds where there is no state primacy under a Federal lands program or whenever the OSMRE issues a permit for surface mining operations. It also can be used by the OSMRE during oversight of approved state programs as a technical guide when assessing the adequacy of bonds, although the states are not compelled to adhere exactly to the methods in the Handbook.

Many primacy states have their own calculation methods. In Colorado, bonds are calculated on a task by task basis with an automated calculation program. Ohio has developed a Performance Security Spreadsheet that engineers use to estimate the cost of reclamation (Interstate Mining Compact Commission 2013).

\subsubsection{Bond release}

According to federal regulations that implement the Surface Mining Control and Reclamation Act, the release of the bond can be divided into three phases. Each phase has specific reclamation completion criteria. Phase 1 release may occur after the operator completes the backfilling, regrading, and surface water drainage control of the bonded area in accordance with the approved reclamation plan. After completing this phase, $60 \%$ of the bond or collateral for the applicable permit area can be released. Phase 2 release may occur after vegetation has been established on the backfilled and regraded mined area in accordance with the approved reclamation plan. The amount of bond released for Phase 2 is an additional 25\% of the total reclamation bond. Phase 3 release may occur after the mining company has successfully completed all mining and reclamation requirements in the permit. After Phase 3, the remaining $15 \%$ of the bond is released.

Based on the three-phase release specified by the Act, primacy states may make their own guidance. For example, in Wyoming, bond release includes a total area release, as well as Phase 1, Phase 2, and Phase 3 incremental bond release. Each phase has the performance standards the operator must meet (Krzyszowska-Waitkus and Blake 2011). Some states minimize the use of phased-bond release especially where long term water treatment is a possibility.

\subsubsection{Public participation}

The Surface Mining Control and Reclamation Act made detailed provisions for public participation in the release of the bond. Citizens can attend public hearings, be aware of mining activities through notices in local news outlets, write or deliver personal comments to regulators, and request visits to the mining area.

\subsection{Canada}

In Canada, mining companies have been required by law to reclaim all lands disturbed by mining since 1969 (Technical and Research Committee on Reclamation 2010). All the provincial and territorial governments in Canada have legislation in place to provide financial assurance for reclamation in the event the mine operator is unable to do so (Fraser Institute 2015). After the mining company conducts the proper site reclamation, the financial security deposit is returned to the company.

\subsubsection{Laws and Regulations}

Unlike the United States, laws and regulations for mine reclamation and bonding in Canada reside primarily at a provincial level. For example, the British Columbia Ministry of Energy, Mines and Petroleum Resources sets out criteria and the Mines Act requires a company to estimate the cost of reclamation and establish the bond amount (CCSG Associates 2001). In Alberta, reclamation certificates are required for mining operations as directed by the Environmental Protection and Enhancement Act (Alberta Energy Regulator 2015). In Ontario, the Mining Act of 1990 (Bill 26), Chapter M 14, Part VII covers the requirements and specifies standards, procedures and requirements needed for rehabilitation and closure (World Bank Group 2008).

\subsubsection{Administrative authority}

No national authority exists in Canada. Each province or territory has its own administrative authority over the bond. For example, bonding in the Yukon Territory is regulated by the Department of Indian Affairs and Northern Development and Yukon Territory Water Board (Searle 2000). 
Bonding in Ontario is administered by the Ministry of Northern Development and Mines (World Bank Group 2008), while British Columbia reclamation bonding is administered by the Ministry of Energy and Mines (British Columbia 2015).

\subsubsection{Bond types}

Several bond types are acceptable in Canada including cash, letters of credit, surety bonds, government bonds, trust funds, company guarantees, investment certificates, self-bonds, and combinations of these. Differences exist among provinces. For example, in British Columbia, corporate guarantees and self-bonds are not acceptable types of financial assurance for sites which may have long term water quality and liability concerns (CCSG Associates 2001; World Bank Group 2008). In Alberta, the Mine Financial Security Program is used to collect financial security from the oil sands and coal industry to protect the public from paying for end-of-life project closure costs. It allows for security deposits to be made that will account for potential risks during the life cycle of the mine.

\subsubsection{Size of the bond}

The size of the bond differs among provinces. A survey in 2001 found that most Canadian governments did not calculate security bond amounts equal to the full cost of cleanup. No examples were found of a security bond that was sufficient to cover the full costs of remediating a site (CCSG Associates 2001).

\subsubsection{Bond calculation}

Bond calculation in Canada is generally based on current construction rates and third-party estimates. Contingency surcharges are imposed and range from $10 \%$ to $30 \%$ add-on depending on the degree of uncertainty. British Columbia and Northwest Territories provide a costing spreadsheet to use and others use a reclamation model or a regulatory guide (British Columbia 2015; Cowan et al. 2010).

\subsubsection{Bond release}

In Ontario, the bond may be available for on-going rehabilitation. If some of the work is carried out in accordance with legislative requirements, some of the bond may be released considering the current value of the remaining rehabilitation work. After successful mine closure, the bond is released but some funds may be retained for short term monitoring costs or long term care (World Bank Group 2008). In the Northern Territories, securities are deposited with the Department of Indian and Northern
Affairs (DIAND) and held until reclamation and closure are completed to the satisfaction of DIAND (Searle 2000).

\subsubsection{Public participation}

In Ontario, the public has an opportunity to review closure plans, but the security amounts are not open to public review (World Bank Group 2008). Under British Columbia mining legislation, there are no specific legal requirements mandating public participation in setting mine securities or bonding (Fair Mining Collaborative 2015).

\subsection{Australia}

All Australian states have a requirement to elicit a security deposit by the leaseholder against possible failure to rehabilitate or meet the environmental requirements after mining (McLeod 2000).

\subsubsection{Laws and regulations}

Laws about bonding vary among Australian states. For example, in Western Australia, provisions for reclamation bonding are encompassed in the Mining Act of 1978. In Queensland, the Mineral Resources Act of 1989 requires that a "security" is deposited prior to a mining title being issued. The Environmental Protection Act of 1994 requires the rehabilitation program to include the proposed amount of the financial surety for larger projects while the Codes of Environmental Compliance require a financial surety for small projects. A single surety can be used to cover the requirement of both the Mineral Resources Act and the Environmental Protection Act (World Bank Group 2008).

\subsubsection{Administrative authority}

Each state has its own administrative authority for bonding. For example, the Department of Mines and Petroleum of Western Australia administers mining securities on behalf of the Minister, in accordance with the provisions of the Mining Act of 1978. Bonding requirements are guided by departmental policy and administrative procedures (Government of Western Australia 2010). In Queensland, the Department of Mines and Energy is responsible for the receipt and management of both the security under the Mineral Resources Act and the financial surety under the Environmental Protection Act (World Bank Group 2008).

\subsubsection{Bond type}

Bond types differ among Australian states. Acceptable forms of financial surety in Queensland include cash, bank guarantees, letters of credit, and insurance bonds. In 
Western Australia, before 2014, the bond type was usually in the form of a performance bond fully guaranteed by a bank or other acceptable financial institution, which must show the name of the licensee. It should not be in the form of cash. A performance bond is a contract between the Minister for Mines and Petroleum and a third-party of financial standing acceptable to the Minister. The thirdparty will unconditionally pay an agreed sum to the Minister upon his request following the failure of the mining company to meet environmental commitments (Government of Western Australia 2010). Since July 2014, except in cases of high risk, the majority of mining companies are not required to provide a bond for future approvals. Participation in the bonding fund is compulsory except for mining companies with a rehabilitation liability estimate below a threshold of $\$ 50000$ (Government of Western Australia 2014).

\subsubsection{Size of the bond}

In Western Australia, the Department of Mines and Petroleum recommended that the performance bond be set at a level to encourage reclamation. It is based on a set of predetermined criteria that relate to the estimated cost of remediation and may not necessarily reflect the actual reclamation cost. The bond covers all the land disturbed and will be reviewed annually and increased or decreased depending on the total area disturbed and the area successfully reclaimed (Government of Western Australia 2014). In Queensland, bonds for exploration and small standard mining projects are based on the total area of disturbance and the risk associated with rehabilitation. The bond amount for a non-standard project is made on a project-specific basis (World Bank Group 2008).

\subsubsection{Bond calculation}

There are large differences among states as to how the bond amount is calculated. In Queensland, the amount of financial assurance is calculated by determining the cost to reclaim the site minus any applicable discounts. To obtain a discount, a set of mandatory criteria must first be met (World Bank Group 2008). In Western Australia, the calculation method for performance bonds uses a minimum bond rate based on the mine's surface area disturbance, with minimum bond rates for small areas (Government of Western Australia 2014).

\subsubsection{Bond release}

In Western Australia, the full bond amount can be returned to the company when the mine closure standards have been met and all environmental regulations have been achieved.
There will also be bond reduction if progressive reclamation has been carried out (Government of Western Australia 2014). In Queensland, the financial surety is not available for on-going reclamation. However, when a new mining operation plan is submitted and the reclamation liability is recalculated, work that has been completed will no longer be included in the total. The financial surety remains in place until the Environmental Protection Agency is satisfied that no further claim is likely to be made against it (World Bank Group 2008).

\subsubsection{Public participation}

In Queensland, the government will no longer accept selfbonds as a financial surety instrument because public opinion has no faith in them (World Bank Group 2008). In Victoria, there is no third-party involvement in establishing the financial surety and no process of verification (World Bank Group 2008).

\subsection{China}

\subsubsection{Laws and regulations}

The first real attention for land reclamation in China was in the 1980s. In 1986, the Land Management Law was passed by the Sixth National People's Congress, which was the first time China addressed reclamation in the law. It specified that the company causing a land disturbance should be responsible for reclamation, recovery, and land utilization after mining. It remains as the only national law on reclamation in China.

The Land Reclamation Regulation (LRR), effective in 1989, was then promulgated by the State Council, which stipulated definitions, planning and management of land reclamation. In 2006, the Ministry of Land and Resources issued the Notice of Strengthening Land Reclamation Management Work of Production and Construction Projects (NSLR), which incorporated a reclamation plan in the mining license and approval process. In 2011, the State Council issued the Land Reclamation Ordinance (LRO), which revised the 1989 Land Reclamation Regulation. Compared with the 1989 Land Reclamation Regulation, the 2011 Land Reclamation Ordinance further defined the responsibility of mining companies, establishing that reclamation plans are part of the permitting process and that reclamation monitoring and supervision should occur. Over the past 30 years, China's reclamation rate of disturbed land has been increased from $1 \%$ in 1987 to $25 \%$ at present (Liu 2011).

Zhejiang Province was the first province in China to implement a mine reclamation bonding system in 1998 (Cheng and Hu 2008). By 2013, all 31 provinces (including 
autonomous regions and municipalities that are directly under the central government) had established a reclamation bonding system and over 70000 mines have paid a reclamation bond (Ministry of Land and Resources 2013), which accounts for $80 \%$ of the total number of mines.

Three policies were issued that helped to establish mine reclamation bond systems in the 31 provinces of China (Cheng and Hu 2008). The policies were: (1) The Notice on the Comprehensive Rectification and Standardization of Mineral Resources Exploitation Order (NCRS) issued in 2005; (2) Guidance on the Gradual Establishment of the Responsibility Mechanism of Mine Environment Management and Ecological Restoration (GERM) issued in 2006; (3) Provisions on the Protection of Mine Geological Environment (PPMGE) issued in 2009.

Each policy enhanced procedures and helped to further develop a mine reclamation bonding system. For example, the GERM stipulated that the local Ministry of Finance, the department of Land Resources, and the department of Environmental Protection in each province should jointly determine the amount of the reclamation bond based on mineral type, size of mine disturbance, mineral output, sales income of mineral products, the design life of the mine, environmental treatments, ecological recovery rate, and reclamation cost.

Besides the above three national policies, each province has made their own regulations and implementation measures of mine reclamation bond. There are no specific laws and regulations at the national level.

\subsubsection{Administrative authority}

There is no national administrative authority that oversees reclamation standards or bonding. Most provinces stipulate that administrative departments of land and resources at or above the county level calculate, collect, and release bonds.

\subsubsection{Bond types}

There is no national standard for the types of financial instruments that can be used for reclamation bonds in China. Except Shandong Province, reclamation bonds in the other 30 provinces can only be in the form of cash. In 2015, Shandong Province specified that the bond submitted can be in cash or other non-cash guarantee forms such as performance bonds or letters of credit provided by a bank. The non-cash bond in Shandong Province must be submitted to the Department of Land and Resources. The cash bond in most provinces is required to be deposited directly into a special financial or bank account jointly administered by the financial department, the Department of Land and Resources, and the mining company.

\subsubsection{Size of the bond}

Most provinces collect the reclamation bond according to the principle of "not lower than the treatment fee." For example, administrators of mine reclamation bonds in Tianjin municipality, Shandong province, and Anhui province all stipulate that 'the bond collected should not be lower than the treatment fee.'

\subsubsection{Bond calculation}

There is no unified bond calculation method in China. Some provinces calculate the bond based solely or in combination with the mineral type, the mining area, a percentage of sales revenue, and the mineral output. Most provinces use a combination of these criteria to form a basis (Cheng 2009). For example, Guizhou Province determines the amount of bond according to mineral type, the designed mining scale, and the valid period of the mining permit. Zhejiang Province calculates the bond according to the designed mining scale and a scaling coefficient based on the depth of mining disturbance.

\subsubsection{Bond release}

Most provinces stipulate that the bond shall be released at one time after all the reclamation work is finished if the period of the permit is less than 3 years. Bonds for those mines whose permit period is more than 3 years shall be released after each reclamation phase is fulfilled. But most of the provinces do not make detailed reclamation standards for each phase in their regulations or the standards are not specific.

\subsubsection{Public participation}

There is no public participation allowed in the regulations of China's 31 provinces concerning the collection and release of bonds, nor in the enforcement of regulations and reclamation standards.

\section{Comparison and discussion}

Table 1 summarizes current mine reclamation bonding policies in the United States, Canada, Australia and China.

\subsection{Laws and administrative authority}

Laws and administrative authority provide that the reclamation bonding system has legal status and is enforced. From the above table, it can be seen that among the four countries, only the United States has a law and 
administrative authority for reclamation bonding at the national level. There are no laws or administrative authority for reclamation bonds at the national level in Canada and Australia, and each province/state has its own reclamation laws and administrative authority. In China, national laws and regulations and administrative authority for reclamation bonding also do not exist. Rather, each province has its own regulation of bonds and the bond is usually administered by departments of land and resources at or above the county level in each province.

Compared to provincial or state laws and regulations, national laws help to establish a unified and standardized reclamation bonding system, which must be based on fair and enforceable nationwide reclamation standards for mining companies. National laws also have greater weight and binding force for implementing reclamation standards and bond systems. Before the Surface Mining Control and Reclamation Act in the United States, some states had their own laws governing surface mining, but these state laws varied widely, enabling mining operations to relocate to states where regulations were less strict. The passage of the Surface Mining Control and Reclamation Act equalized reclamation standards across states and provided a baseline of procedures for reclamation practices, enforcement, and bonding. A national regulatory authority of bonding (the OSMRE) was also created. Reclamation bonds are required for all active mines throughout the country. If the mine permit applicant cannot submit the bond according to the provisions in the Surface Mining Control and Reclamation Act, supervised by the OSMRE, the company will not be granted a mine permit anywhere in the country.

\subsection{Bond type}

The United States, Canada, and Australia accept a variety of financial instruments and assets for reclamation bonds including cash, corporate assets, letters of credit, real estate, surety bonds, insurance bonds, trusts, and bond pools. In China, only Shandong Province uses non-cash bonds but has only approved this circumstance since 2015 . All other provinces in China accept only cash bonds.

Financial assurance is usually divided into hard and soft assurance (Miller 1998). The hard forms involve cash and company assets that are placed in an account. The soft forms of assurance are based on liens and lines of credit. Even these forms of assurance represent a significant burden in that they reduce the credit rating and borrowing ability of the company (Miller 2005). With the economic burden caused by reclamation bonds, many companies have turned to bond pools where allowed. Reclamation bonds composed of a combination of hard and soft funds may be more acceptable in the future (Searle 2000).
Although a cash bond may be a preferred type for administrative authorities because of low risk as stated above, a desirable bonding system should form economic incentives rather than economic burdens for mining companies (Cheng 2009). There is evidence that the high cost of bonding sharply reduces investment in and by the mining industry. Cash bonds are expected when the credit or strength of the mining company is unknown or questionable, or the permit time is short. But cash bonds impose great liquidity constraint and economic burdens on many companies, particularly small companies, and other types of bonding types should be allowed for more established and reputable companies.

Self-bonding is coming under particular scrutiny. In the United States, self-bonding for coal companies tops $\$ 3.3$ billion nationwide, which includes $\$ 2.3$ billion in liabilities (Gruver 2016). As the industry declines, more companies, who were previously strong and solvent, have filed for bankruptcy (Mufson and Warrick 2016). In some cases, money available to cover the cost of reclamation was not posted as a bond, and the company had no financial reserve to complete reclamation and environmental cleanup (Gruver 2016). Therefore, there has been a move away from self-bonding. The states of New Mexico and Nevada in the United States limit self-bonding to no more than $75 \%$ of a company's reclamation liability (Conrad 2014).

\subsection{Size of bond and calculation method}

The core of a reclamation bonding system is the size and the method of calculation for the bond amount. If the amount calculated is too small, there will be a huge capital gap for reclamation and the land will be left unreclaimed or result in a great financial burden to the government and community to reclaim the operation once the mining company forfeits their reclamation obligation. If the size calculated is too large, it will negatively impact the mining company's fiscal capacity and potentially affect mine development (Cheng 2009).

Among the four countries, Canada does not calculate bond amounts equal to the full cost of reclamation and bond amounts in Australia do not necessarily reflect the actual cost. China's level is not lower than the treatment fee. None of these countries have a unified calculation method at the national level. Only the United States calculates bond amounts at a third-party reclamation cost and has unified the calculation method with rules established by the OSMRE.

A preferred mechanism of a reclamation bonding system is that the bond amount be sufficient for a third-party to do the reclamation work and supervised by the administrative authority. The cost should also include all administrative, maintenance, and monitoring costs (World Bank Group 
Table 1 Comparison of mine reclamation bonding system in the United States, Canada, Australia and China

\begin{tabular}{|c|c|c|c|c|}
\hline Item & United States & Canada & Australia & China \\
\hline $\begin{array}{l}\text { Laws and } \\
\text { regulations }\end{array}$ & $\begin{array}{l}\text { Surface Mining Control and } \\
\text { Reclamation Act } \\
\text { (SMCRA) with } \\
\text { accompanying state laws at } \\
\text { least as stringent as } \\
\text { national law }\end{array}$ & $\begin{array}{l}\text { No specific national laws and } \\
\text { regulations. Each province } \\
\text { or territory has its own law }\end{array}$ & $\begin{array}{l}\text { No specific national laws and } \\
\text { regulations. Each state has } \\
\text { its own law }\end{array}$ & $\begin{array}{l}\text { No specific national laws and } \\
\text { regulations. Each province } \\
\text { has its own }\end{array}$ \\
\hline $\begin{array}{l}\text { Administrative } \\
\text { authority }\end{array}$ & $\begin{array}{l}\text { State mine reclamation } \\
\text { agency, with oversight by } \\
\text { the federal OSMRE. Non- } \\
\text { primacy states are directly } \\
\text { administered by OSMRE }\end{array}$ & $\begin{array}{l}\text { No national administrative } \\
\text { authority, each province } \\
\text { has its own administrative } \\
\text { authority }\end{array}$ & $\begin{array}{l}\text { No national administrative } \\
\text { authority, each state has its } \\
\text { own administrative } \\
\text { authority }\end{array}$ & $\begin{array}{l}\text { No national administrative } \\
\text { authority, bond is } \\
\text { administered by } \\
\text { departments of land and } \\
\text { resources at or above } \\
\text { county level in each } \\
\text { province }\end{array}$ \\
\hline Bond type & $\begin{array}{l}\text { Major bond types include } \\
\text { cash, corporate surety } \\
\text { bonds, self-bonds, } \\
\text { certificates of deposit, first- } \\
\text { lien interests in real estate, } \\
\text { letters of credit, federal, } \\
\text { state, or municipal bonds, } \\
\text { investment-grade securities } \\
\text { etc } \\
\text { Some states use bond pool } \\
\text { and trust funds }\end{array}$ & $\begin{array}{l}\text { Bond types differ among } \\
\text { provinces and territories, } \\
\text { but include cash, letters of } \\
\text { credit, corporate surety } \\
\text { bonds, government bonds, } \\
\text { trust funds, company } \\
\text { guarantees, investment- } \\
\text { grade securities etc }\end{array}$ & $\begin{array}{l}\text { Bond types differ among } \\
\text { states, but include cash, } \\
\text { letters of credit, bank } \\
\text { guarantees, insurance } \\
\text { bonds, etc. Some states use } \\
\text { Mining Rehabilitation } \\
\text { Fund }\end{array}$ & $\begin{array}{l}\text { Only Shandong province } \\
\text { allows non-cash bonds. } \\
\text { All other provinces only } \\
\text { use cash }\end{array}$ \\
\hline $\begin{array}{l}\text { Size of the } \\
\text { bond }\end{array}$ & $\begin{array}{l}\text { The bond amount would be } \\
\text { sufficient to engage a third- } \\
\text { party contractor to } \\
\text { complete the reclamation } \\
\text { plan, and reflects the worst- } \\
\text { case scenario }\end{array}$ & $\begin{array}{l}\text { Most provinces and } \\
\text { territories do not calculate } \\
\text { security bond amounts } \\
\text { equal to the full cost of } \\
\text { reclamation }\end{array}$ & $\begin{array}{l}\text { The bond does not reflect the } \\
\text { actual cost }\end{array}$ & $\begin{array}{l}\text { Not lower than the treatment } \\
\text { feeor reclamation cost }\end{array}$ \\
\hline $\begin{array}{l}\text { Calculation } \\
\text { method }\end{array}$ & $\begin{array}{l}\text { Directed by Handbook for } \\
\text { Calculation of Reclamation } \\
\text { Bond Amounts, written by } \\
\text { OSMRE }\end{array}$ & $\begin{array}{l}\text { Differs among provinces and } \\
\text { territories }\end{array}$ & Differs among states & $\begin{array}{l}\text { No unified calculation } \\
\text { method, differs among } \\
\text { provinces }\end{array}$ \\
\hline Bond release & $\begin{array}{l}\text { Phased-release with clear } \\
\text { reclamation criteria }\end{array}$ & $\begin{array}{l}\text { Primarily one-time release at } \\
\text { closure }\end{array}$ & $\begin{array}{l}\text { Primarily one-time release at } \\
\text { closure }\end{array}$ & $\begin{array}{l}\text { One-time release if permit } \\
\text { time is below } 3 \text { years. } \\
\text { Phased-release beyond } \\
3 \text { years, but no criteria for } \\
\text { each phase or the criteria } \\
\text { is vague }\end{array}$ \\
\hline $\begin{array}{l}\text { Public } \\
\text { participation }\end{array}$ & Stipulated by SMCRA & Partial public participation & Partial public participation & No public participation \\
\hline
\end{tabular}

2008). In Canada, the lack of calculating the reclamation bond with a third-party and administration cost analysis has decreased incentives for companies to act responsibly and complete reclamation and closure, and therefore increases the risk to public financial resources and health (CCSG Associates 2001). In China, few mining companies reclaim the disturbed land, or have any of the bond refunded, because the bond amount paid is lower than the reclamation costs (Xiao et al. 2010; Yan et al. 2012). This defeats the original intention of a bonding system which should be to encourage mining companies to fulfill reclamation obligations and have the bond money returned. Bond calculations based on a third-party reclamation cost provides an incentive for a company to complete reclamation work by itself because it can do so less expensively than a third-party (CCSG Associates 2001). A unified bond calculation method can help to ensure the adequacy of bond amounts and will contribute to fairness among mining companies for reclamation.

\subsection{Bond release}

Release of the bond is the important final key piece of a bonding system. The United States releases mine 
reclamation bonds according to a three-phase schedule stipulated by the federal regulations that implement the Surface Mining Control and Reclamation Act with each stage having its own clear criteria. In Canada and Australia, bond reduction is allowed for on-going reclamation, but most of the bond is retained until mine closure.

In China, the bond is usually released at the end of reclamation if the permit time is less than 3 years. If the permit time is more than 3 years, bonds can be phase-released but most provinces do not have reclamation criteria for incremental bond release at each stage. For example, in Jilin province, a company can apply for release of bond money when they have partially or fully completed reclamation work, which is determined by the regulatory authority. The authority has 20 days to make an evaluation after which they may release part or all of the bond based on their evaluation of the company's reclamation. There are no specific criteria about the evaluation defined in the law and therefore the release of bonds is difficult to implement in practice.

Phased-bond release can reduce the economic burden on a mining company and encourage and stimulate a more proactive approach to progressive reclamation. It also embodies the principle of concurrent reclamation and promotes the idea that mining companies should reclaim disturbed land actively and timely (Cheng 2010a, b). Reclamation standards should be clearly defined so that the reclamation work is properly done and evaluations can be done in a timely and efficient manner.

\subsection{Public participation}

Among these four countries, only the United States stipulates public participation in the law. There is no public participation or only partial public participation in the reclamation bonding systems of the other three countries. Public participation allows local citizens and communities to engage in the mining and reclamation process. It allows for greater collection and access of information about the disturbed site, and can promote cooperation and coordination of the mining activity and reclamation procedures. Allowing for public input helps to avoid wrong decisions by the regulatory authority, can reduce administrative and supervision costs, and can promote fairness, justice and accountability (Environmental Defender's Office NSW 2011).

\section{Recommendations for China}

\subsection{Establish a national law to unify and standardize reclamation bonding system}

Currently, reclamation bonds in 31 provinces are diverse and regulated by provincial laws. A national law should be established to unify and standardize the content of reclamation bonding system to create a fair and competitive environment for mining enterprises. Since all 31 provinces in China have implemented land reclamation bonds with regulations, refinements can be made for a national law from the procedures already established in provincial laws.

\subsection{Create a special national administrative authority with power to implement the reclamation bonding system}

An entity like the OSMRE in the United States could be created within the Ministry of Land and Resources, with branches in each province. This special administrative authority would be responsible for the regulation, enforcement, evaluation, collection, calculation, and release of reclamation bonds. Under the direction of this authority, a nationwide unified reclamation bond system could be established to create fair and enforceable standards with realistic reclamation costs for mining companies. The bonds can be based on a per unit reclamation cost.

\subsection{Expand bond types}

Besides cash, other non-cash bonds and financial instruments should be promoted to lessen the economic burden on mining companies. Expanding the types of bonds available can be applied gradually (Cheng 2010a, b). Initially, some types of less "hard" bonds such as letters of credit, trust funds, deposits of security, or a combination of financial assurances along with cash can be available for companies to use as financial collateral. Later, other "soft" types of financial securities such as corporate assets and investments can be adopted. Self-bonding is not recommended because of the experiences in other countries of company bankruptcies and that no reserves of funds are available to complete the reclamation work (Riley and Isidore 2016; Corkery 2016). Research about bond types and their suitable conditions should also be carried out by academia.

\subsection{Set the size of reclamation bond at the level of the third-party reclamation cost and unify the calculation method}

The size of reclamation bonds should be set at the level of a third-party reclamation cost to ensure sufficient funding for the administrative authority to complete reclamation and to encourage reclamation and closure by the mining company. The calculation method should also be unified and based on standardized costs for mining companies. The administrative authority should provide guidance and publish the 
bond calculation methods so that the methods are known and widely available. Related research should also be carried out by academia to discover the most practical and effective ways, and provide theoretical support for bond calculations.

\subsection{Unify the phases of bond release and establish detailed reclamation criteria and the corresponding amount released for each phase}

There should be a nationally unified release criteria that allows phased-release of bonds. Supporting rules and regulations should also be formulated. Detailed reclamation criteria and the amount released for each phase and procedures of release should be clearly stipulated.

\subsection{Stipulate full public participation in legislation}

Public participation in reclamation bonding systems should be promoted. All the information on the standards, collection, use and release of the bond should be open to the public. Public evaluation and opinion, methods and procedures of engagement, and channels for communication should be stipulated in legislation to ensure the public can fully participate in the reclamation bonding system.

\section{Conclusions}

The comparisons in this paper show that the United States has a more mature and unified reclamation bonding system than the other three countries. Although controversies and problems still exist where companies do not secure enough bonds, do not update their liabilities during mining process, the system in the United States has been highly successful in helping companies be responsible for reclamation liabilities. More than $80 \%$ of the land disturbed since 1977 has been reclaimed. As a country that implemented mine reclamation bonding system only recently, China can adopt laws and regulations that clearly work well from the experience of other countries and improve many aspects of the reclamation bonding system including the passage of a national law and regulations, creating a national administrative authority, expanding bond types, unifying bond calculation methods to determine the size of bonds, establishing bond release criteria, and allowing for full public participation in the reclamation system. Recommendations for the above aspects outlined in this paper are beneficial for the establishment of a healthy and sustainable bonding system in China and a healthy and competitive mining industry.
Acknowledgements This study was supported by National Natural Science Foundation of China (No. 41401637) and China Scholarship Council (No. 201406435027). This article is scientific article \#3305 from the Agricultural and Forestry Experiment Station, West Virginia University, Morgantown, WV.

\section{Compliance with ethical standards}

Conflicts of interest The authors declare no conflict of interest.

Open Access This article is distributed under the terms of the Creative Commons Attribution 4.0 International License (http://crea tivecommons.org/licenses/by/4.0/), which permits unrestricted use, distribution, and reproduction in any medium, provided you give appropriate credit to the original author(s) and the source, provide a link to the Creative Commons license, and indicate if changes were made.

\section{References}

Alberta Energy Regulator (2015) Abandonment and reclamation https://www.aer.ca/abandonment-and-reclamation/reclamation. Accessed 10 Nov 2016

British Columbia (2015) Permitting and reclamation http://www. empr.gov.bc.ca/Mining/Permitting-Reclamation/Pages/default. aspx. Accessed 15 July 2016

CCSG Associates (2001) Financial option for the remediation of mine sites: a preliminary study. Report to Mining Watch Canada, Ottawa, Ontario, 2001. http://www.miningwatch.ca/sites/www. miningwatch.ca/files/financial_options_paper_0.pdf. Accessed 16 Oct 2016

Cheng L (2009) Study on the mode of mine reclamation bond of China. Ph.D. thesis, China University of Mining and Technology (Beijing), Beijing, China (in Chinese with English abstract)

Cheng L (2010a) Study on the release of mine land reclamation performance bond in China. In: Proceedings, 2010 IEEE international conference on advanced management science, vol 2, pp 658-661

Cheng L (2010b) Designs of the form and operation mode of mine reclamation bond. Coal Econ Res 30(5):15-18

Cheng L, Hu Z (2008) Study on the land reclamation performance bonds systems in mineral areas in China. China Mining Magazine 17:18-19 (in Chinese with English abstract)

Conrad GE (2014) Mine reclamation bonding-from dilemma to crisis to reinvention: what's a state regulator to do? Interstate Mining Compact Commission. February 11, 2014. http://www. imcc.isa.us/EMLF\%20Bonding\%20Presentation\%20Final.pdf. Accessed 16 Oct 2016

Corkery M (2016) Regulators fear $\$ 1$ billion coal cleanup bill. New York Times. June 6, 2016. http://www.nytimes.com/2016/06/07/ business/dealbook/regulators-fear-1-billion-coal-cleanup-bill. html?_r=0. Accessed 16 Oct 2016

Cowan W, Mackasey W, Robertson J (2010) The policy frame work in Canada for mine closure and management of long term liabilities: a guidance document. http://www.abandoned-mines. org/pdfs/PolicyFrameworkCanforMinClosureandMgmtLiabil ities.pdf. Accessed 21 Aug 2016

Environmental Defender's Office NSW (2011) Mining law in New South Wales. http://d3n8a8pro7vhmx.cloudfront.net/edonsw/ pages/285/attachments/original/1380667551/110628mining_ law_discussion_paper.pdf?1380667551. Accessed 16 Oct 2016

Fair Mining Collaborative (2015) Securing the cost of mine clean-up: public participation. http://www.fairmining.ca/code/securing- 
the-cost-of-mine-clean-up-2/public-participation/. Accessed 21 Aug 2016

Fedkenheuer A, Macyk T (2000) Reclamation of surface mined coal lands in western Canada. In: Barnhisel R, Darmody R, Daniels W (eds) Reclamation of Drastically Disturbed Lands. Agronomy 41. Soil Science Society of America, Madison

Fraser Institute (2015) What happens to mine sites after a mine is closed? Mining facts. http://www.miningfacts.org/Environment/ What-happens-to-mine-sites-after-a-mine-is-closed/. Accessed 15 July 2016

Gerard D (2000) The law and economics of reclamation bonds. Resour Policy 26:189-197

Gorman J, Skousen J, Sencindiver J, Ziemkiewicz P (2001) Forest productivity and minesoil development under a white pine plantation versus natural vegetation after 30 years. In: Proceedings, 18th annual meeting, American Society for Surface Mining and Reclamation, 2-7 June, 2001, Albuquerque, NM, pp 103-111

Gorton WT (2013) State and federal reclamation bonding programs: lessons learned and current challenges. In: 2013 National Bonding Workshop, St. Louis, MI. Interstate Mining Compact Commission. http://www.imcc.isa.us/Bill\%20Gorton\%20Paper. pdf. Accessed 16 Oct 2016

Government of Western Australia (2010) The Mining Rehabilitation Fund - the first two years. Department of Mines and Petroleum. http://www.dmp.wa.gov.au/Documents/Environment/MRF_ The_First_Two_Years.pdf. Accessed 16 Oct 2016

Government of Western Australia (2014) Mining Rehabilitation Fund. Fact sheet May 2014 compulsory year. Department of Mines and Petroleum. http://www.dmp.wa.gov.au/Documents/Environ ment/ENV-MEB-381.pdf. Accessed 21 Aug 2016

Gruver M (2016) Mine environmental risk grows with bankruptcies in big coal. Associated Press. http://bigstory.ap.org/article/ 2b8ae16e1f8e42e7b1af97584ec1cf99/mine-environmental-riskgrows-bankruptcies-big-coal. Accessed 16 Aug 2016

$\mathrm{Hu}$ ZQ (2009) Review and prospect of land reclamation and ecological restoration in China. Sci Tech Rev 27(17):25-29 (in Chinese with English abstract)

Interstate Mining Compact Commission (2013) Bonding survey report: coal. August 2013. http://www.imcc.isa.us/BondingSur vey2013Final.pdf. Accessed 16 Oct 2016

Krzyszowska-Waitkus A, Blake C (2011) Tracking bond release at a large Wyoming coal mining operation. In: Proceedings, American Society of Mining and Reclamation. Lexington, Kentucky, pp 338-350

Liu Z (2011) To give land life and vigor - Interpretation of "Land reclamation ordinance" by the director of policy and regulations of the Ministry of Land and Resources. Land Resour Commun 5:12-13

Luo M, Wang J (2010) The Enlightenment to China from the construction of land reclamation system and the research of science and technology in Australia. China Land 4:51-53

MacDonald E, Landhausser S, Skousen J, Franklin J, Frouz J, Hall S, Jacobs D, Quideau S (2015) Forest restoration following surface mining disturbance: challenges and solutions. New For 46:703-732

Marks M, Buchta T, Newman C, Lentz R, Gabardi J, Werner P, DeTar B, Curry T, Doran M (2004) Training guide for reclamation bond estimation and administration. USDA-Forest Service, April 2004. http://www.fs.fed.us/geology/bond_guide_ 042004.pdf. Accessed 10 Nov 2016

McLeod H (2000) A review of the bond system in Fiji. SOPAC Technical Report 305, December 2000. http://ict.sopac.org/ VirLib/TR0305.pdf. Accessed 16 Oct 2016
Miller G (1998) Use of financial surety for environmental purposes. International Council on Metals and the Environment. http:// www.icme.com/icme/finsurety.htm. Accessed 10 July 2016

Miller G (2005) Financial assurance for mine closure and reclamation. https://www.icmm.com/document/282. Accessed 15 Oct 2016

Ministry of Land and Resources (2013) 2013 land resources bulletin. http://www.mlr.gov.cn. Accessed 15 July 2016

Mufson S, Warrick J (2016) Can coal companies afford to clean up coal country? Washington Post. April 2, 2016. https://www. washingtonpost.com/business/economy/can-coal-companiesafford-to-clean-up-coal-country/2016/04/01/c175570c-ec7311e5-a6f3-21ccdbc5f74e_story.html. Accessed 16 Aug 2016

Office of Surface Mining Reclamation and Enforcement (2000a) Handbook for calculation of reclamation bond amounts. USDIOSMRE, October 2000. http://www.osmre.gov/LRG/docs/direc tive882.pdf. Accessed 16 Oct 2016

Office of Surface Mining Reclamation and Enforcement (2000b) Chronology of major SMCRA-related events. USDI-OSMRE, October 2000. http://www.osmre.gov/LRG/chronlisting.shtm. Accessed 16 Oct 2016

Office of Surface Mining Reclamation and Enforcement (2016) Reclamation performance bonds. http://www.osmre.gov/ resources/bonds/bondsoverview.shtm. Accessed 16 Oct 2016

Power CB (2010) SMCRA primacy, mining permit transfers, ownership and control, and excess reclamation responsibilities: a primer on confusing topics. Energy Miner Law Inst 31:268-297

Riley C, Isidore C (2016) The largest U.S. coal company just filed for bankruptcy. CNN. April 13, 2016. http://money.cnn.com/2016/ 04/13/news/companies/peabody-coal-bankruptcy/. Accessed 16 Oct 2016

Searle D (2000) Reclamation and bonding in the North. Department of Indian and Northern Affairs (DIAND), Canada. http://www. miningnorth.com/_rsc/site-content/library/reclam $\% 20 \%$ 20bond\%20-\%20reprint.pdf

Shogren J, Herrigies J, Govindasamy R (1993) Limits to environmental bonds. Ecol Econ 8:109-133

Skousen J, Zipper C (2014) Post-mining policies and practices in the Eastern USA coal region. Int J Coal Sci Technol 1:135-151

Skousen J, Ziemkiewicz P, Venable C (2006) Tree recruitment and growth on 20-yr-old, unreclaimed surface mined lands in West Virginia. Int J Min Reclam Environ 20:142-154

Slezak M, Robertson J (2016) Full of holes: why Australia's mining boom will leave permanent scars. The Guardian. https://www. theguardian.com/environment/2016/jul/20/full-holes-australiamining-boom-permanent-scars. Accessed 16 Oct 2016

Technical and Research Committee on Reclamation (2010) Mining and reclamation in British Columbia, Canada http://technology. infomine.com/reviews/reclamationbc/welcome.asp?view=full (accessed 16 Oct 2016)

World Bank Group (2008) Guidance notes for the implementation of financial surety for mine closure. The World Bank Group of the Oil, Gas and Mining Policy Division. http://siteresources. worldbank.org/INTOGMC/Resources/financial_surety_mine. pdf. Accessed 21 Aug 2016

Xiao W, Hu Z, Xu X (2010) Cost definite method of land reclamation in coal mining area. J China Coal Soc 35(S1):175-179

Yan S, Shen W, Zou C (2012) Theory and practice of deposit system for restoration and control of mining environment. Environ Sci Technol 35(6I):423-427

Zipper C, Burger J, Skousen J, Angel P, Barton C, Davis V, Franklin J (2011) Restoring forests and associated ecosystem services on Appalachian coal surface mines. Environ Manag 47:751-765 